
\title{
28 Research Suare \\ Effect of COVID 19 on Perceived Stress, Coping Skills, Self-Control and Self-Management Skills
}

\section{Onur Altuntaş ( $\square$ fztonurb@hotmail.com )}

Hacettepe Universitesi Saglik Bilimleri Fakultesi https://orcid.org/0000-0002-2403-2096

\section{Yasin Tekeci}

Hacettepe Universitesi

\section{Research}

Keywords: Covid-19, stress, coping with stress, self-control, self-management, anxiety

Posted Date: July 30th, 2020

DOI: https://doi.org/10.21203/rs.3.rs-48393/v1

License: (1) (1) This work is licensed under a Creative Commons Attribution 4.0 International License. Read Full License 


\section{Abstract}

Background: The COVID-19 is a major health crisis affecting th whole world. Purpose: The aim of the study was to investigate the effects of the COVID-19 on perceived stress, ways of coping with stress, self-control and selfmanagement skills.

Methods: This study was conducted on 882 participants. The Perceived Stress Scale, Stress Coping Style Scale, Self-Control \& Self-Management Scale were used to assess participants' perceived stress, coping stress strategies self-control skills.

Results: The total score of the perceived stress of 882 participants were found to be $28.35 \pm 8.23$. It is seen that $60.3 \%$ of the participants have moderate level stress. Seeking of social support is the most preferred coping strategy.

Conclusions: In our study, it has seen that people have moderate stress levels during the pandemic process. It is predicted that strategies such as social support and improve self-control skills play an important role to keep people's stress balance or reducing along that period.

\section{Background}

Coronaviruses are a large family of viruses that cause a variety of diseases, from the common cold to more serious diseases such as the Middle East Respiratory Syndrome and Severe Acute Respiratory Syndrome. It can cause clinical pictures in humans and animals with various degrees of respiratory, enteric, hepatic, nephrotic and neurological involvements (https://covid19bilgi.saglik.gov.tr/tr).

With the measures taken by our country, the Coronavirus Disease 2019 (COVID-19) was delayed as much as possible. After the first case described in Turkey on 11th March 2020, people were asked to stay at home and socially isolate themselves to prevent being infected. The schools were closed for this term and the distance education process started. A flexible working model was started by initiating administrative permissions in public/private institutions and organizations. Some firms that do not need to be urgent, important and permanent have stopped their jobs. Places such as cafes, restaurants, entertainment venues, shopping malls were closed and the service was temporarily stopped in these places. In this process, people receive online and telephone services. Afterward, a curfew was introduced to the people aged 65 and over and then to the people aged 20 and below, and they were restricted to go out in non-compulsory situations (https://covid19bilgi.saglik.gov.tr/tr).

COVID-19 affects the life, health and well-being of individuals, families and communities around the worldwide. Uncertainty of the duration of the process, the situation of those whose relatives or themselves are affected by this disease, loss of routine, social distancing, financial and familial problems can cause stress during this period. People can get stressed and live in a troubled environment. Those who have familial problems, those who live alone, those who have no one to communicate can also be seen more (https://www.nccn.org/covid19/pdf/Distress-Management-Clinician-COVID-19.pdf).

This pandemic process, which is seen as a major public health problem, can be seen as a loss of autonomy by some people. There are also people who spend time outside and do not care about public health, as well as those who respect me for protecting public health and preventing harm to the public, by staying at home, preferably 
with self-control and self-management. The self-management and self-control process is also thought to play an important role in dealing with this negative pandemic process.

The COVID-19 has capable to increase stress and anxiety, due to the fear of having the virus and uncertainty about how the outbreak will affect us socially and financially (https://covid19bilgi.saglik.gov.tr/tr/). Increased anxiety is common as we navigate COVID-19 and the broad impacts to our communities. It is a normal, natural response to have increased emotions during this time of uncertainty, including feelings such as anxiety, sadness, problems in self- control and self-management, disappointment, and confusion (https://www.nccn.org/covid19/pdf/Distress-Management-Clinician-COVID-19.pdf). COVID-19 has broken every aspect of daily living, engendering isolation and social distance, financial problems, fears of contracting a potentially lethal illness and feelings of helplessness and hopelessness (Ozamiz et al., 2020). It has seen that people were given experienced suggestions for the stresses encountered in an atmosphere whose limits and end could be predicted in a known life flow (Polizzi et al., 2020; Brooks et al., 2020). However, current pandemic process we have experienced has changed the flow of life all over the world and has caused many uncertainties about how life will continue from now on. Therefore, in the pandemic process, to develop effective strategies to adapt to the new life during the crisis it is important to investigate both the psychological situation and the pandemic's psychological impact on populations. With this study, we aimed to investigate the stress levels of people during the pandemic period, which strategies they use to deal with stress, whether they can maintain their self-control and self-management or not.

\section{Methods}

\section{Study Designfper}

This is a cross-sectional exploratory-descriptive study. The study was conducted in April 2020-May 2020 in Turkey.

\section{Place of the Research}

The research was carried out by creating an online form as it is to determine how the residents were affected by this process. For the sample collection techniques, given the unfolding situation with the COVID-19 outbreak, the choice was made to use a Google Forms, which was sent to individuals via online social platforms (Whatsapp, Facebook). The study protocol was approved by .... University Ethical Committee (No: GO 20/396; 2020/08-38; 17.04.2020). The procedures followed were in accordance with the ethical standards of relevant institutional and consistent with the Helsinki Declaration.

\section{Participants}

Among 882 people that participated in our study, $512(58 \%)$ were female and $370(42 \%)$ were male. The inclusion criteria were participants who (a) were literate, (b) were aged between 14 and 65 years (c) were able to understand and follow administration criteria, and (d) were accessed internet. 


\section{Measurement tools}

All participants were asked questions such as age, gender, whether they went out during the pandemic process, how many people lived at home.

The Perceived Stress Scale (PSS) was developed by Cohen et al. (1983). Consisting of 14 items in total, PSS is designed to measure how stressful some situations in a person's life are perceived. The participants evaluate each item on a 5-point Likert scale ranging from never (0) to very often (4). Scores of PSS vary between 0 and 56 points. The high score indicates the excessive perception of the person's stress. A score of 42-56 points indicates high stress level, 27-41 points indicates moderate stress level, and 11-26 indicates low stress level. The adaptation of the PSS into Turkish is conducted by Eskin et. al. (2013).

Stress Coping Style Scale (SCSS) was developed by Şahin \& Durak (1995). This test consists of 5 subscale and 30 items. These sub-scales are consist of self-confident approach (SCA), optimistic approach (OA), helpless approach (HA), submissive approach (SA), and seeking of social support (SSSA). Among these sub-dimensions, SCA, OA, and SSSA sub-dimensions are considered as "effective methods" in terms of coping with stress. HA and SA are considered as "ineffective methods". Separate scores were obtained from the subscales of the scale in Likert type. This scale is evaluated between 0 and $3(0=0 \%, 1=30 \%, 2=70 \%, 3=100 \%)$. Subscale scores are obtained by dividing the scores from each subscale by the number of items in the relevant subscale. The high scores obtained from the subscales are interpreted as the person's using the related coping style more (Şahin, et al 1995).

The Self-Control and Self-Management Scale (SCMS) was developed by Mezo (2009), and its Turkish validity and reliability was provided by Ercoskun (2016). The SCMS; consists of three subscales: Self-Monitoring (SM), Self-Evaluating (SE), and Self-Reinforcing (SR). It is a 6-point Likert-type scale consisting of 16 items. The total score that can be obtained from the scale varies between 0 to 80 points. In SM stage, the individual monitors some behavior targeted for change or maintenance and draws attention to informative stimuli. In the stage of SE, the individual compares the target behavior and internalized standard. The individual passes judgment on whether the monitored stimuli progresses towards valuable targets or not. The individual engages in SR which can be either open or secret and involves self-rewarding or selfpunishment (Kanfer, 1970; Bandura, 1991; Mezo, 2009; Mezo \& Short, 2012).

\section{Statistical analysis}

The answers were collected via Google form and exported to Excel for analysis with the SPSS statistical package, version 22.0. The demographic information for the participations were summarised by descriptive statistics. The perceived stress level, the self control-self management skills, and the ways of coping with stress differ according to the demographic variable; Independent t-test in bivariate demographic features was analyzed with One-Way ANOVA in demographic features with more than two variables. Levene test was used to assess to homogeneit of the variences. When there is a statistical difference as a result of One-Way ANOVA analysis, it is determined by which groups it is caused by Post Hoc tests. When variances are homogeneous, Bonferroni test is used among in our study. When variances are not homogeneous, Tamahne T2 test is used among in our study. We performed correlation analysis to examine the association between perceived severity, self-control and mental health problems. Pearson correlation analysis was to examine the association between the perceived stress level, 
the self control-self mangement skills, and the ways of coping with stress (Altunışık et al., 2010; Sipahi et al., 2010).

\section{Results}

The distribution of the participants in the current study by age groups were 328 people in the in the age range of 14 to 17 years old, 357 people in the age range of 18 to 30 years. During the pandemic process, 571 of the participants never left the house, 160 of them left very rarely, 151 of them left the house from time to time. It was determined that only 25 of the 882 participants lived alone at home, and the other participants shared the home with a partner. The mean score of stress perceived by age distribution, 328 people in the in the age range of 14 to 17 years old had middle stress; 357 people in the age range of 18 to 30 years old had moderate stress (Tables 1 ).

Table 1

Mean score of the perceived stress levels by age ranges

\begin{tabular}{|llll|}
\hline Age ranges & $\mathbf{n}$ & $\begin{array}{l}\text { PSS } \\
\mathbf{X} \pm \text { SD }\end{array}$ & Minimum-maximum \\
\hline $14-17$ age & 328 & $28.07 \pm 9.10$ & $0-52$ \\
\hline $18-30$ age & 357 & $29.64 \pm 7.93$ & $1-52$ \\
\hline $31-40$ age & 86 & $26.38 \pm 7.40$ & $8-44$ \\
\hline $41-50$ age & 56 & $26.21 \pm 6.05$ & $9-49$ \\
\hline $51-60$ age & 45 & $27.35 \pm 6.15$ & $14-46$ \\
\hline $61-65$ age & 10 & $24.80 \pm 6.89$ & $10-34$ \\
\hline Total & 882 & $28.35 \pm 8.23$ & $0-32$ \\
\hline The Perceived Stress Scale: PSS; Standard Deviation: SD \\
\hline
\end{tabular}

The perceived stress levels according to different age groups were compared using one-way analysis of variance and a significant difference was found between the groups. Since the Levene statistic [(2.611) p: 0.024] was found, the variance of the groups was not homogeneous. Accordingly, a significant difference was found in terms of perceived stress between the individuals between the ages of 18-30 and those between the ages of 31$40(M=3.26, S D=0.90)$. Similarly, a significant difference was found between the individuals between the ages of $18-30$ and those between the ages of $41-50(M=3.43, S D=0.91)$ in terms of perceived stress. The stress level perceived by the participants between the ages of 18-30 is higher than the other two groups. It was determined that there was no significant difference between the other age groups in terms of perceived stress level.

The total score in terms of perceived stress of 882 participants was found to be $28.35 \pm 8.23$. According to the subscale mean scores of the SCSS; SCA was found to be $1.57 \pm 0.54$, HA was found to be $1.22 \pm 0.62$, SA was found to be $0.87 \pm 0.51$, OA was found to be $1.63 \pm 0.64$, and SSSA was found to be $2.17 \pm 0.70$. The total score of SCMS was found to be $48.84 \pm 14.07$. According to, the subscale means scores of the SCMS; SM was found to be $20.16 \pm 7.43$, SE was found to be $12.06 \pm 6.12$ and SR was found to be $16.61 \pm 6.74$. 
$60.3 \%$ (n: 532) of the participants have moderate level stress and $35.5 \%$ (n: 313 ) of participants have a low level of stress. $4.2 \%$ (n: 37$)$ of participants have high level stress level. The perceived stress distributions according to stay home; of the 571 participants who never left the house, 188 were found to have low stress, 360 to moderate and 23 to high stress. Of the 160 participants who rarely left the house, 66 were found to have low, 87 were moderate and 7 had high levels of stress. Of the 151 participants who leaving home carefully, 59 were found to have low stress, 85 to moderate and 7 to high stress.

According to gender of the subscale mean scores of the SCSS; mean scores of perceived stress level for men were higher than women $(p=0.001)$. According to the analysis whether the styles of coping with the stress of the participants differed by gender, it was found that there was a significant difference in the subscale of the SSSA $(p<0.05)$, there was no difference in the other subscales $(p>0.05)$. According to analysis whether self-control and self-management skills of the participants differed by gender, it was found that there was a significant difference in total score and in the subscale of $S E(p<0.05)$, and there was no difference in the other subscales $(p>0.05)$. Table 2 reveals gender differences in the perceived stress, the various stress coping strategies, and the self-control\&self-manaegement skills. 
Table 2

Gender and Perceived Stress Level, Stress Coping Strategies, Self-Control and Self-Management Skills

\begin{tabular}{|c|c|c|c|c|c|}
\hline & Gender & $\mathbf{n}$ & $X \pm S D$ & $t$ & $p$ \\
\hline \multirow[t]{2}{*}{ PSS } & $\mathrm{M}$ & 370 & $29.29 \pm 10.03$ & \multirow[t]{2}{*}{2.874} & \multirow[t]{2}{*}{$0.001 *$} \\
\hline & $\mathrm{F}$ & 512 & $27.68 \pm 8.34$ & & \\
\hline \multirow[t]{2}{*}{ SCA } & $\mathrm{M}$ & 370 & $1.58 \pm 0.56$ & \multirow[t]{2}{*}{-.347} & \multirow[t]{2}{*}{0.729} \\
\hline & $\mathrm{F}$ & 512 & $1.59 \pm 0.53$ & & \\
\hline \multirow[t]{2}{*}{$\mathrm{HA}$} & $\mathrm{M}$ & 370 & $1.21 \pm 0.62$ & \multirow[t]{2}{*}{-.744} & \multirow[t]{2}{*}{0.457} \\
\hline & $\mathrm{F}$ & 512 & $1.24 \pm 0.62$ & & \\
\hline \multirow[t]{2}{*}{ SA } & $\mathrm{M}$ & 370 & $0.87 \pm 0.50$ & \multirow{2}{*}{-.077} & \multirow[t]{2}{*}{0.939} \\
\hline & $\mathrm{F}$ & 512 & $0.87 \pm 0.52$ & & \\
\hline \multirow[t]{2}{*}{ OA } & M & 370 & $1.60 \pm 0.63$ & \multirow[t]{2}{*}{-1.332} & \multirow[t]{2}{*}{0.183} \\
\hline & $\mathrm{F}$ & 512 & $1.66 \pm 0.66$ & & \\
\hline \multirow[t]{2}{*}{ SSSA } & $M$ & 370 & $1.93 \pm 0.69$ & \multirow[t]{2}{*}{-9.094} & \multirow[t]{2}{*}{$0.001^{\star}$} \\
\hline & $\mathrm{F}$ & 512 & $2.35 \pm 0.67$ & & \\
\hline \multirow[t]{2}{*}{ SMMS } & $\mathrm{M}$ & 370 & $51.97 \pm 14.05$ & \multirow[t]{2}{*}{5.726} & \multirow[t]{2}{*}{$0.001 *$} \\
\hline & $\mathrm{F}$ & 512 & $46.57 \pm 13.65$ & & \\
\hline \multirow[t]{2}{*}{ SM } & $\mathrm{M}$ & 370 & $20.58 \pm 7.35$ & \multirow[t]{2}{*}{1.400} & \multirow[t]{2}{*}{0.162} \\
\hline & $\mathrm{F}$ & 512 & $19.87 \pm 7.49$ & & \\
\hline \multirow[t]{2}{*}{ SE } & $\mathrm{M}$ & 370 & $14.41 \pm 5.21$ & \multirow[t]{2}{*}{10.279} & \multirow[t]{2}{*}{$0.001 *$} \\
\hline & $\mathrm{F}$ & 512 & $10.35 \pm 6.17$ & & \\
\hline \multirow[t]{2}{*}{ SR } & M & 370 & $19.67 \pm 6.57$ & \multirow[t]{2}{*}{1.365} & \multirow[t]{2}{*}{0.172} \\
\hline & $\mathrm{F}$ & 512 & $16.34 \pm 6.88$ & & \\
\hline
\end{tabular}

It is stated that the percieved stress in all 3 levels, seeking of social support is the most preferred coping strategy for stress, and submissive approach is the least preferred coping strategy for stress (Table 3). 
Table 3

Mean score of preferred coping strategies based on perceived stress level

\begin{tabular}{|llllll|}
\hline PSS & SCSS- SCA & SCSS- HA & SCSS- SA & SCSS-OA & SCSS- SSSA \\
\hline & $\mathrm{X} \pm$ SD & $\mathrm{X} \pm \mathrm{SD}$ & $\mathrm{X} \pm$ SD & $\mathrm{X} \pm \mathrm{SD}$ & $\mathrm{X} \pm$ SD \\
\hline Low stress level (11-26) & $1.69 \pm 0.59$ & $1.03 \pm 0.6$ & $0.82 \pm 0.51$ & $1.79 \pm 0.67$ & $2.17 \pm 0.68$ \\
\hline $\begin{array}{l}\text { Medium stress level } \\
(27-41)\end{array}$ & $1.54 \pm 0.50$ & $1.31 \pm 0.6$ & $0.89 \pm 0.51$ & $1.56 \pm 0.62$ & $2.20 \pm 0.69$ \\
\hline High stress level (42-56) & $1.37 \pm 0.56$ & $1.74 \pm 0.56$ & $1.09 \pm 0.42$ & $1.46 \pm 0.68$ & $1.81 \pm 1.03$ \\
\hline Standard Deviation: SD; The Perceived Stress Scale: PSS; the Stress Coping Style Scale: SCSS. \\
\hline
\end{tabular}

The relationship between the total PSS and the SCSS sub-dimensions indicated the self-confident, helpless, submissive and optimistic, respectively (r: - .112, p: 0.001; r: 0.319; p: 0.001; r: .105; p: 0.002; r: - .162, p: 0.001). The correlation coefficient between the PSS and the SCSS social support sub-dimension is not statistically significant $(p>0.05)$. The relationship between the total PSS and the SCMS sub-dimensions indicated that respectively, the self-evaluating and self-reinforcing (r: -.068 , p: 0.044; r: 0.070, p: 0.037). Table 4 shows the relationship between perceived stress, coping with stress strategies and self-control and self-management skills. 
Table 4

Correlations between all variables

\begin{tabular}{|c|c|c|c|c|c|c|c|c|c|c|c|}
\hline & & 1 & 2 & 3 & 4 & 5 & 6 & 7 & 8 & 9 & 10 \\
\hline \multirow[t]{2}{*}{ 1.PSS } & $r$ & 1 & & & & & & & & & \\
\hline & $p$ & - & & & & & & & & & \\
\hline \multirow{2}{*}{2.} & $r$ & $-.112^{\star \star}$ & 1 & & & & & & & & \\
\hline & $p$ & .001 & & & & & & & & & \\
\hline \multirow[t]{2}{*}{ 3. $\mathrm{HA}$} & $r$ & $.319^{\star *}$ & $-.116^{\star \star}$ & 1 & & & & & & & \\
\hline & $p$ & .001 & .001 & & & & & & & & \\
\hline \multirow[t]{2}{*}{ 4. SA } & $r$ & $.105^{\star \star}$ & .049 & $.528^{\star \star}$ & 1 & & & & & & \\
\hline & $p$ & .002 & .150 & .001 & & & & & & & \\
\hline \multirow[t]{2}{*}{ 5. OA } & $r$ & $-.162^{\star \star}$ & $.713^{\star *}$ & $-.115^{\star \star}$ & $.141^{\star \star}$ & 1 & & & & & \\
\hline & $p$ & .001 & .000 & .001 & .001 & & & & & & \\
\hline \multirow{2}{*}{ S. } & $r$ & -.010 & $.189^{\star \star}$ & $.166^{\star \star}$ & .028 & $.125^{\star \star}$ & 1 & & & & \\
\hline & $p$ & .766 & .001 & .001 & .398 & .001 & & & & & \\
\hline \multirow{2}{*}{ S. } & $r$ & .028 & $.296^{\star *}$ & -.039 & $-.083^{*}$ & $.218^{\star \star}$ & -.036 & 1 & & & \\
\hline & $p$ & .399 & .001 & .247 & .014 & .001 & .290 & & & & \\
\hline \multirow[t]{2}{*}{ 8. SM } & $r$ & .046 & $.346^{\star *}$ & -.064 & $-.094^{\star *}$ & $.234^{\star *}$ & .049 & $.831^{* *}$ & 1 & & \\
\hline & $p$ & .172 & .001 & .058 & .005 & .001 & .145 & .001 & & & \\
\hline \multirow[t]{2}{*}{ 9. SE } & $r$ & $-.068^{\star}$ & $-.077^{\star}$ & -.028 & .008 & -.045 & $-.322^{\star *}$ & $.383^{\star *}$ & -.060 & 1 & \\
\hline & $p$ & .044 & .022 & .402 & .821 & .185 & .000 & .000 & .075 & & \\
\hline \multirow[t]{2}{*}{$\begin{array}{l}10 . \\
\text { SR }\end{array}$} & $r$ & $.070^{*}$ & $.306^{\star *}$ & .015 & $-.075^{\star}$ & $.237^{\star \star}$ & $.164^{\star \star}$ & $.822^{\star *}$ & $.685^{\star \star}$ & -.044 & 1 \\
\hline & $p$ & .037 & .001 & .665 & .025 & .001 & .001 & .001 & .001 & .195 & \\
\hline
\end{tabular}

\section{Discussion}

The current study investigated the effects of the COVID 19 on perceived stress, ways of coping with stress, selfcontrol and self-management skills. It was seen that the people participating in our study had moderate stress. In addition, the fact that 313 people who participated in this study affecting the whole world had low stress levels is another result. There could be various explanations. Stress is an element that threatens the organism from inside and outside. The amount of stress keeps the person alert and supports them to survive. When the person is 
directly exposed to the stressful situation, the perceived stress level increases

(https://www.medicalnewstoday.com/articles/145855). It is thought that the majority of the people who participated in our study never left the house in this process and the possibility of encountering the virus directly, contributed to the moderate and low stress levels. COVID-19 is a virus identified on January 13, 2020 in China.

The first case was seen on March 11, 2020 in our country and the quarantine process was initiated for this case (Chen Q et al., 2020; https://covid19bilgi.saglik.gov.tr/tr/). There may have been more information on the virus (via transmission routes and the protection of social distance is the best protection measure) in Turkey, since it arrived there two months and a half after China, and such knowledge of the pandemic might explain the moderate levels of stress. At the same time, during this period, it is thought that the incautiousness of the institutions regarding the things to be done in dealing with the pandemic and making statements about the situation by the Minister of Health provide a sense of trust in the people and the perceived stress is at a moderate level. However, when the normalization process begins, it is thought that it is important to examine the stress conditions related to adaptation to the external environment.

According to the results, there were higher mean levels of stress in the 18-30 year age stage, followed by the 1417 year stage. Finally, the mean levels of stress were lowest in individuals 61 years and older. Since the youngest people of the sample in this study was mostly high school/ university students, these symptoms may have been due to the additional stress experienced by young students during the need to adapt to the new online distance education system, to graduate from school, to seek a new job after the graduation.

According to the results, it is stated that the level of the perceived stress of men is higher than women. Literally, it is stated in the studies conducted on this topic that the PSS scores of women are higher than men (Hamad et al., 2008). In a study by Day et al. (2003) with 186 university students found that in three of the five scenarios women are more stressed than men. it has seen that the results of our study were differenced the studies presented from literature. The reason for this is more likely that women's habit of spending time at home is better than men. In addition, it is thought that women's better social connections with others contribute to this. Sometimes these links are important for stress management strategies.

Different levels of perceived stress differentiate coping strategies (Trewor \& Enright, 1990). In our study, it is seen that all strategies are used in different rates to deal with stress. This is thought to be due to the difference of stress sources and perceived stress level, environmental and social factors.

Coping strategies are methods developed by the individual to counteract internal or external effects that cause tension in the individual. Lazarus (1991) has been defined as the consciously formed strategies of the individual against coping with stress and the negative life events that the person experiences. It is the individual's active response to stressful situations during coping or preferring to lower the threat level of the stress source more passively (Özbay \& Şahin, 1997; Folkman \& Lazarus, 1988).

In our study, the most preferred strategy to deal with stress is that it is a seeking of social support strategy; the least preferred strategy is the submissive strategy. In addition, individuals with three perceived stress levels have the most seeking of social support strategy; at the very least, it appears to use the submissive strategy.

When the Turkish social structure is analyzed, it is seen that the basis of social aid and solidarity goes back to the first Turkish communities. The important days such as birth, death, mourning, joy, grief, soldier farewell, wedding, etc. in cases, the person is assisted and supported (Yazılıtaş, 2002). When the individual, who is part of 
the culture they are in, encounters a problem, they will seek help from their close circle to solve it. It is believed that people who seek solutions and balance in normal individual events seek help from their immediate surroundings by seeking greater support as part of the culture in larger events. It is thought that the majority of the people who participated in our study are the ones who live together at home during this process, which is also a factor in their preference for this strategy.

In a study carried out by Ergin et.al. (2014), it was found that the students used the self confident strategy method the most in their way of dealing with stress. The least used strategy is seeking of social support. The self-confident approach, one of the ways to deal with stress, means that the person finds himself in the power to resist and fight in any situation (Dennis et al., 2010).

In our study, it was also determined that women used the seeking of social support strategy more than men, which is one of the strategies to deal with stress. Social support, seen in close situations in difficult situations, has a role in reducing the effects of stressful events. This support makes people feel valued to eliminate the stressor or reduce its effect. This strategy is a strategy that is mostly evaluated in relation to human relations. In our study, it is thought that women's perception of stress is lower than men and that they use communication based this strategy more effectively.

Self-control and self-management skills are based on the circulation of the individual seeing, evaluating and moving the dynamics they have on the eve of having a new experience (Mezo, 2009). If the experience turns out to be positive, the individual encourages himself for new experiences, and if it turns out to be negative, the circulation stops or changes (Kanfer and Karoly, 1972). A study by Li and colleagues shows that individuals with low self-control are more vulnerable to maintain their mental health in the COVID-19 outbreak and need more psychological help.

In our study, it was found that the participants were also successful in using self-control self-management strategies. This situation shows us that the participants have successfully used the strategies that help them to manage their behaviors about suddenly reducing the inconsistencies in externally determined standards. Also, having high self-management and self-control skills shows that they know themselves and what they can do. When we look at the difference in terms of gender, for it is seen that men are more successful in using these strategies. Especially, it is seen that this difference arises in self-evaluation. Contrary to the findings that gender management strategies are in favor of women and men, there are also findings that there is no significant difference between them. (Uğurluoğlu, 2010; Covarrubias \& Stone, 2015; Kurman, 2001; Kazan, 1999; Razieh et al., 2013; Carmelivet al., 2006). According to the gender variable in a study by Ercoşkun; it is stated that there is a significant difference in favor of female teacher candidates in self-adjustment, self-assessment, selfreinforcement sub-dimensions and total score.

When considered the relationship between perceived stress level and stress coping strategies in the current study; it has been determined that there is a low and negative relationship between perceived stress level and selfconfident approach and optimistic approach. It was found that there was a weak and positive relation between perceived stress level and the submissive approach and helpless approach. There was no relation between perceived stress level and the seeking of social support approach. These results reveal that the use of effective ways to cope with stress reduces perceived stress and the use of ineffective ways increase this level. 
In a study examining the relation between the PSS and the SCSS subscale; it has been determined there is a negative and weak relation between perceived stress level and self-confident and optimistic approach. It has a positive and weak relation between perceived stress level and helpless and submissive approach sub-dimension. The correlation coefficient between the PSS and the seeking social support approach is not statistically significant (Savcı and Aysan, 2014).

Low and negative correlations were found with the perceived stress level and SE. A weak and positive correlation was detected between the perceived stress level and SR. In this case, as the perceived stress level by the person increases, the self-evaluation decreases and the problems arise in interpreting the person's internal balance. As people strengthen and control themselves, the stress they perceive decreases.

Self-management consists of a series of strategies that facilitate the behaviors that are used to reduce deviations from existing standards so that the individuals can manage their own behavior (Manz, 1986). Individuals with high self-management and self-control skills know themselves and what they can do and are successful in many areas in their lives.

It has been determined that self-monitoring has a weak and positive relation with a self-confident approach and optimism approach, and a low and negative relationship with a submissive approach. It has been determined that self-evaluating has a weak and negative relation with a self-confident approach and seeking of social support. It was found that self-reinforcing has a low and positive relation with a self-confident approach, an optimistic approach, and seeking of social support, and a weak and negative relation with submissive. In this case, it shows us that self-management and self-control increases as we use effective coping strategies of individuals.

In his study with 302 university students, Savcl et. al. (2014) found that there was a low and positive correlation between perceived stress level and strategies to cope with stress. In a study conducted by Tekin et al.(2019), there was a significant and negative relationship between seeking social support, self-confident approach and optimistic approach, and stress level, while there was a significant and positive relationship between submissive approach and helpless approach and stress level.

\section{Limitation of the Study}

A number of limitations noted for this study. Firstly, the ages of the participants have mostly consisted of young population and women. In the pandemic process, the study was carried out on the online form due to social isolation. Since the use of technology is not enough for people over a certain age, they have difficulty in accessing them. Therefore, it is seen that the population using technology is more intense in our study. Secondly, this survey was based on self-report instruments that could introduce a systematic bias.

\section{Conclusion}

As a result of the data obtained in our study, it was seen that the people participating in our study had moderate stress. It is thought that the high levels of self-control/ and the use of social support seeking strategy are the factors that affect the perceived stress. In this difficult period, it was observed that people did not complicate their lives by taking extreme precautions and did not risk their lives by acting entirely without precaution but 
instead they manage this process in a controlled manner by remaining in moderate stress. It is thought that it will be beneficial to cope with this process while preparing stress coping programs, including activities that contain social support and development of self-management and self-control skills. It is suggested to investigate the psychosocial situation and whether the permanent effects of perceived stress in the normalization process after COVID 19.

Key messages

- Recognize that your stres is completely normal. But you can do a lot about coping with stress.

- Help your friends who feel lonely too.

- If you keep feeling bad, talk to your parent, grandparent, a trusted adult or friends.

\section{List Of Abbreviations}

Coronavirus Disease 2019 : COVID-19

The Perceived Stress Scale: PSS

the Stress Coping Style Scale: SCSS

Self-confident approach: SCA

Optimistic Approach: OA

Helpless Approach: HA

Submissive Approach: SA

Seeking of Social Support: SSS

The Self-Control and Self-Management Scale: SCSMS

Self-monitoring: SM

Self-Evaluating: SE

Self-Reinforcing: SR.

Female: $\mathrm{F}$

Male: $\mathrm{M}$

Standard Deviation: SD

\section{Declarations}

Ethics approval and consent to participate 
The study protocol was approved by Hacettepe University Ethical Committee (No: GO 20/396; 2020/08-38;

17.04.2020).

\section{Consent for publication}

The procedures followed were in accordance with the ethical standards of relevant institutional and consistent with the Helsinki Declaration.

\section{Availability of data and materials}

Data sharing is not applicable to this article as no datasets were generated or analysed during the current study.

\section{Competing interests}

The authors declare that they have no competing interests

\section{Funding}

The authors declare that they have no funding.

\section{Authors' contributions}

OA and YT analyzed and interpreted the data regarding the study. OA and YT wrote the manuscript together. All authors read and approved the final manuscript.

\section{Acknowledgements}

Not applicable

\section{References}

1. Altunışık R, Coşkun R, Bayraktaroğlu S, Yıldırım E. Sosyal Bilimlerde Araştırma Yöntemleri. Sakarya Kitabevi; 2005.

2. Bandura A. Social cognitive theory of self-regulation. Organ Behav Hum Decis Process. 1991;50(2): 248287. https://doi.org/10.1016/0749-5978(91)90022-L.

3. Brooks S, Webster RK, Smith LE, Woodland L, Wessely S, Greenberg N. et. al. (2000). The psychological impact of quarantine and how to reduce it: rapid review of the evidence. Lancet. 2000; 395(10227): 912920. https://doi.org/ 10.1016/S0140-6736(20)30460-8.

4. Carmeli A, Meitar R, Weisberg J. (2006). Self-leadership skills and work innovative behavior at work. International Journal of Manpower. 2006; 27(1): 75-90. 
5. Chen Q, Liang M, Li Y, Guo J, Fei D, Wang L. et al. Mental health care for medical staff in China during the COVID-19 outbreak. Lancet Psychiatry. 2020;7:e15-6.

6. Cohen S, Kamarck T, Mermelstein, R. A global measure of perceived stress. J Health Soc Behav. 1983; 24(4): 385-396. https://doi.org/10.2307/2136404

7. Covarrubias R, Stone J. Self-monitoring strategies as a unique predictor of Latino male student achievement. Journal of Latinos and Education. 2015; 14: 55-70.

8. Yeni Corona Virüs Hastalığı. https://covid19bilgi.saglik.gov.tr/tr/ accessed date: 4 May 2020.

9. Day AL, Livingstone HA. (2003). Gender differences in perceptions of stressors and utilization of social support among university students. Can J Behav Sci. 2003; 35(2): 73-83.

https://doi.org/10.1037/h0087190

10. Dennis JP, Vander Wal JS. (2010). The cognitive flexibility inventory: instrument development and estimates of reliability and validity. Cognit Ther Res. 2010; 34(3):241-253.

11. Eskin M, Harlak H, Demirkıran F, Dereboy Ç. (2013). Algılanan Stres Ölçeğinin Türkçeye uyarlanması: güvenirlik ve geçerlik analizi. New Symposium Journal. 2013; 51(3): 132-140.

12. Ercoşkun MH. (2016). Özkontrol-Özyönetim Ölçeğinin Türk kültürüne uyarlanması: geçerlik ve güvenirlik çalışması. Kuram ve Uygulamada Eğitim Bilimleri. 2016; 16(4):1125-1145.

13. Ergin A, Uzun SU, Bozkurt Ai. The methods of coping with the stress among medical faculty students and the relationship between sociodemographic characteristics and these methods. Firat Med J. 2014;19(1): 31-37.

14. Folkman S, Lazarus RS. Coping as a mediator of emotion. J Person Soc Psychol. 1988; 54: 466-75.

15. Hamad R, Fernald L, Karlan D, Zinman J. Social and economic correlates of depressive symptoms and perceived stres in South African Adults. J Epidemiol Commun H. 2008; 62: 538-544.

16. Kanfer FH. (1970). Self-monitoring: Methodological limitations and clinical applications. Journal of Consulting and Clinical Psychology. 1970;35(2): 148-152.

17. Kanfer FH, \&Karoly P. (1972). Self-control: A behavioristic excursion into the lion's den. Behavior Therapy. 1972; 3(3): 398-416.

18. Kazan AL. Exploring the concept of self-leadership: Factor impacting self leadership of Ohio AmeriCorps members (Unpublished Doctoral dissertation).The Ohio State University; 1999.

19. Kurman J. Self-regulation strategies in achievement setting: culture and gender differences. Journal of Cross-Cultural Psychology. 2001; 32(4): 491-503.

20. Lazarus RS. Emotion and adaptation. Oxford University Press; 1991.

21. Manz CC. Self-leadership: Toward an expanded theory of self-influence processes in organizations. Academy of Management Review. 1986; 11(3): 585-600.

22. Mezo PG. The Self-Control and Self-Management Scale: Development of an adaptive self-regulatory coping skills instrument. Journal of Psychopathology and Behavioral Assessment. 2009; 31(2): 83-93.

23. Mezo PG, Short MM. (2012). Construct validity and confirmatory factor analysis of the self-control and selfmanagement scale. Canadian Journal of Behavioural Science. 2012; 44(1): 1-8.

24. Ozamiz-Etxebarria N, Dosil-Santamaria M, Picaza-Gorrochategui M, Idoiaga-Mondrago N. (2020). Stress, anxiety, and depression levels in the initial stage of the COVID-19 outbreak in a population sample in the northern Spain Cad Saúde Pública. 2020; 36(4): e00054020. 
25. Özbay Y, Şahin B. Stresle Başa Çıkma Tutumları Envanteri: geçerlik ve güvenirlik çalışması. IV. Ulusal Psikolojik Danışma ve Rehberlik Kongresi. Ankara: 1-3 Eylül 1997.

26. Polizzi C, Lynn SL, Perry A. Stress and coping in the time of COVID-19: pathways to resilience and recovery. Clinical Neuropsychiatry. 2020; 17(2): 59-62.

27. Razieh A, Reza H, Saeid R. The analysis of relationship between self-leadership strategies and components of quantum organization at universities. International Journal of Academic Research in Economics and Management Sciences. 2013; 2(5): 192-203.

28. Savcı M, Aysan F. Üniversite öğrencilerinde algılanan stres düzeyi ile stresle ile başaçıkma stratejileri arasındaki ilişki. Uluslararası Türk Eğitim Bilimleri Dergisi. 2014; 3: 44-56.

29. Self-Care and Stress Management During the COVID-19 Crisis: Toolkit for Oncology Health Care Professionals. https://www.nccn.org/covid-19/pdf/Distress-Management-Clinician-COVID-19.pdf Accessed date: 25 May 2020

30. Sipahi B, Yurtkoru ES, Çinko M. Sosyal Bilimlerde SPSS'le Veri Analizi. Beta; 2008.

31. Şahin, NH, Durak A. Stresle Başaçıkma Tarzları Ölçeği: üniversite öğrencileri için uyarlanması. Türk Psikoloji Dergisi. 1995; 10(34): 56-73.

32. Tekin Y, Çilesiz Z, Gede S. Farklı meslek gruplarında çalışanların algılanan stres düzeyleri ve stresle başa çıkma tarzları üzerine bir araştırma. Ordu Üniversitesi Sosyal Bilimler Araştırmaları Dergisi. 2019; 9(1): 79-89.

33. Trevor JP, Enright SJ. (1990). Anxiety and Stress Management. London: Routledge.

34. Uğurluoğlu Ö. Kendi kendine liderlik stratejileri üzerine bir araştırma. Ankara Üniversitesi İktisadi ve İdari Bilimler Dergisi. 1990; 24(1): 175-191.

35. Why stress happens and how to manage it. https://www.medicalnewstoday.com/articles/145855 Accessed date: 25 May 2020.

36. Yazılıtaş N. Türk toplum hayatında sosyal yardımlaşma ve dayanışmanın tarihi temellerine bir bakış. Nüsha. 2002; 5(2): 163-171. 